\title{
Combined Soil and Foliar Nitrogen Fertilization Effects on Rainfed Almond Tree Performance
}

\author{
Maria C. Morais ${ }^{1}$ (D) - Alfredo Aires ${ }^{1} \cdot$ David Barreales $^{2} \cdot$ M. Ângelo Rodrigues ${ }^{2} \cdot$ António C. Ribeiro $^{2}$ • \\ Berta Gonçalves ${ }^{1,3} \cdot$ Ana P. Silva ${ }^{1,4}$
}

Received: 14 February 2020 / Accepted: 7 August 2020

(C) Sociedad Chilena de la Ciencia del Suelo 2020

\begin{abstract}
Cultivation of almond in the Mediterranean region is traditionally done under rainfed conditions and poorly established cropping practices resulting in low yields. Despite the importance of nitrogen $(\mathrm{N})$ fertilization to increase yield in cultivated species, this practice is usually neglected in rainfed managed almond orchards. Selection of the most appropriate rate and method of nitrogen (N) application are utmost factors to maximize almond yield in the considered conditions. Therefore, the aim of this study was to understand how soil and foliar $\mathrm{N}$ fertilization affect physiological and biochemical performance, almond yield, and fruit quality of almond trees grown under rainfed conditions. A 3-year experiment comprised four soil-applied $\mathrm{N}$ rates $(0,25,50$, and $100 \mathrm{~kg} \mathrm{ha}^{-1}$ ) with and without $0.5 \%$ foliar $\mathrm{N}$ application of urea during the growing season, which was arranged in a randomized complete block design with three replications. Nitrogen soil fertilization did not influence the leaf gas exchange parameters and the content of photosynthetic pigments but significantly improved almond yield. There were no particular advantages in foliar fertilization. Soil application of small doses of fertilizer (e.g., $25 \mathrm{~kg} \mathrm{~N} \mathrm{ha}^{-1}$ ) per year was optimal for maintaining appropriate physiological behavior of almond trees under the conditions in which the experiment was carried out, without compromise almond yield and fruit quality. Thus, the annual application at $25 \mathrm{~kg} \mathrm{~N} \mathrm{ha}^{-1}$ enables substantial reduction of almond production costs being a positive contribution to environment-friendly farming practices.
\end{abstract}

Keywords Prunus dulcis $\cdot$ Photosynthesis $\cdot$ Biochemical parameters $\cdot$ Yield $\cdot$ Fruit quality $\cdot \mathrm{N}$ fertilization

\section{Introduction}

Almond (Prunus dulcis (Mill.) D.A.Webb.) is one of the most important nut trees grown in the Mediterranean region, due to

Maria C. Morais

cmorais@utad.pt

1 Centre for the Research and Technology of Agro-Environmental and Biological Sciences (CITAB), University of Trás-os-Montes and Alto Douro, Quinta de Prados, 5000-801 Vila Real, Portugal

2 Centro de Investigação de Montanha (CIMO), Instituto Politécnico de Bragança, Campus de Santa Apolónia, 5300-253 Bragança, Portugal

3 Departament of Biology and Environment, School of Life and Environmental Sciences, University of Trás-os-Montes and Alto Douro, Quinta de Prados, 5000-801 Vila Real, Portugal

4 Department of Agronomy, Scholl of Agrarian and Veterinary Sciences, University of Trás-os-Montes and Alto Douro, Quinta de Prados, 5001-801 Vila Real, Portugal its adaptation to drought (Prgomet et al. 2017). In this region, almond is generally confined to marginal and non-irrigated lands. The productivity of such orchards has been quite low due to the traditional growing practices characterized by low inputs of labor, fertilizers, and limited irrigation (Cordeiro and Monteiro 2002). This led to the progressive abandonment of almond cultivation.

Fertilization is an effective practice to increase the plant growth, fruit yield, and quality of production (Kumar and Ahmed 2014). In almonds, nitrogen (N) is one macronutrient required in large amounts (Muhammad et al. 2018) since it is vital for the growth of fruiting wood and for fruit growth and development (Geisseler and Horwath n.d.). Nitrogen is involved in the synthesis of many organic compounds, such as amino acids, proteins, enzymes, and nucleic acids (Carranca et al. 2018). It is linked to photosynthetic capacity and carbon fixation (Khalsa et al. 2017), it participates in cell division and growth of young tissues (Carranca et al. 2018), and it is especially important during flowering and fruit set (Brown and Uriu 1996). Crop yield largely depends on the availability 
and accessibility of $\mathrm{N}$ in the soil (Grzebisz 2013). In fruits, N influences skin color, size, flavor, and composition (Mandapaka et al. 2017). However, under rainfed conditions, $\mathrm{N}$ fertilization is usually neglected but this view tends to change due to the increased importance of this type of agriculture in the Mediterranean countries (Valverde et al. 2015).

Two of the most common fertilization factors which can affect the $\mathrm{N}$ use efficiency are $\mathrm{N}$ rate and $\mathrm{N}$ application method. Nitrogen rates should be adjusted to the almond crop demand, guarantying maximum yield with minimum $\mathrm{N}$ loss (Muhammad et al. 2018). Excessive use of $\mathrm{N}$ has resulted in increasing luxuriant vegetative growth, susceptibility to diseases, such as almond hull rot (Saa et al. 2016), production costs (Hirel et al. 2011), and environmental damage (Weinbaum et al. 1992). Besides, excess $\mathrm{N}$ can depreciate the nutritional quality and bioactive properties of almonds (Aires et al. 2018).

Regarding $\mathrm{N}$ application method, soil and foliar $\mathrm{N}$ fertilization are commonly used in irrigated almond orchards (Arrobas et al. 2019). Saa et al. (2017) concluded that a supplementary fertilization to the almond leaves effectively enhanced spur leaf area, fruit, and leaf nitrogen concentration, but no significant effects on spur survival and/or return bloom were recorded.

Most of the data on $\mathrm{N}$ use in almond was obtained from highly productive irrigated almond orchards and generally suggested that the tree can respond to $\mathrm{N}$ applications up to $300 \mathrm{~kg} \mathrm{ha}^{-1}$ year $^{-1}$ when applied as fertigation (Muhammad et al. 2018; O'Connell et al. 2016). However, under rainfed conditions, little information is available on the proper rate of $\mathrm{N}$ and/or $\mathrm{N}$ application method despite the importance of this knowledge for improving $\mathrm{N}$ use efficiency.

Previous studies on two cultivars of almond (cv. Masbovera and Glorieta) grown under rainfed conditions showed that the application of $\mathrm{N}$ and boron (B) to the soil significantly increased leaf, shell, and hull $\mathrm{N}$ and $\mathrm{B}$ concentrations but leaf sprays of $\mathrm{N}$ and $\mathrm{B}$ did not increase concentration of such nutrients in plant tissues (leaves, fruits, and flowers) (Arrobas et al. 2019). Although leaf $\mathrm{N}$ strongly affects photosynthesis (Regni and Proietti 2019), there is not much information on the effect of $\mathrm{N}$ fertilization on the photosynthetic capacity and overall physiological performance of almond trees under rainfed conditions. Therefore, the aim of this study was to evaluate the influence of soil and foliar $\mathrm{N}$ fertilization on the physiological and biochemical mechanisms of almond trees, as well as on yield and fruit characteristics. We hypothesized that soil and foliar $\mathrm{N}$ fertilization can favorably affect the physiological performance of almond trees and can also improve fruit yield and quality. The findings from this study can help to define the best $\mathrm{N}$ management practices on almond under rainfed poorly productive conditions to optimize yield and fruit characteristics, and reduce the negative effects of $\mathrm{N}$ loss on the environment.

\section{Material and Methods}

\subsection{Site Description}

The field experiment was carried out at Alfândega da Fé in NE Portugal $\left(41^{\circ} 21^{\prime} \mathrm{N}, 6^{\circ} 57^{\prime} \mathrm{W}, 576 \mathrm{~m}\right.$ a.s.l.), on a 12 -year-old commercial almond (Prunus dulcis cv. Masbovera, grafted on GF-677 rootstock) orchard of 9.5 ha, planted at $6 \times 4 \mathrm{~m}$, during three consecutive years (2015 to 2017). The climate is of Mediterranean type (Köppen climate classification: Csb). Long-term data (1971-2010) from the nearest weather station at Mirandela shows an average temperature between $6.3{ }^{\circ} \mathrm{C}$ (January) and $23.9^{\circ} \mathrm{C}$ (August) and a mean annual rainfall of $508.6 \mathrm{~mm}$. Most rainfall occurs in fall and winter. During the study period, 2016 was characterized by high weather instability, especially concerning the rainfall (Fig. 1). The intense and continuous precipitation in spring, during blossom, caused a marked flower drop in most trees, affecting pollination and fruit formation. On the contrary, the first (2015) and the third (2017) years of the experiment were very similar in terms of precipitation (Fig. 1). Meteorological data from an automatic weather station located near the almond orchard indicated that for the study period, the warmest and the coldest months were July 2016 and January 2017, respectively. The field experiment was established in a loamy textured dystric Regosol. At the start of the experiment, soil oxidizable carbon $\mathrm{C}$ was $14.8 \mathrm{~g} \mathrm{~kg}^{-1}$ (Walkley-Black method); total nitrogen (N) was $1.5 \mathrm{~g} \mathrm{~kg}^{-1}$ (Kjeldahl method); $\mathrm{NO}_{3}^{-}$was $55.9 \mathrm{mg} \mathrm{kg}^{-1}$ (2 M KCl, spectrophotometry UV); $\mathrm{NH}_{4}{ }^{+}$was $36.9 \mathrm{mg} \mathrm{kg}^{-1}$ (phenate method for ammonia); extractable boron (B) was $1.2 \mathrm{mg} \mathrm{kg}^{-1}$ (azomethine method); extractable potassium (K) and extractable phosphorus (P) were $151.4 \mathrm{mg} \mathrm{kg}^{-1}$ and $31.0 \mathrm{mg} \mathrm{kg}^{-1}$, respectively (ammonium-lactate method); exchangeable calcium $\left(C_{\mathrm{a}}\right)$, magnesium $(\mathrm{Mg})$, potassium $(\mathrm{K})$, acidity, aluminum (Al), and cation exchange capacity (CEC) were $3.7,0.8,0.4,0.3,0.2$, and $6.1 \mathrm{cmol}_{\mathrm{c}} \mathrm{kg}^{-1}$ (ammonium acetate method, $\mathrm{pH} 7) ; \mathrm{pH}\left(\mathrm{H}_{2} \mathrm{O}\right)$ was 5.2 ; and $\mathrm{pH}(\mathrm{KCl})$ was 4.3.

\subsection{Fertilizer Treatments}

The experiment was conducted through a randomized complete block design with four soil $\mathrm{N}$ fertilization rates $(0,25,50$, and $\left.100 \mathrm{~kg} \mathrm{ha}^{-1}\right)$, applied as ammonium nitrate $(20.5 \% \mathrm{~N})$, and three replications (blocks). In each block, half of the plots were supplemented with three foliar sprays of $\mathrm{N}(0.5 \% \mathrm{~N}$ as urea (46\%), $4.4 \mathrm{~L}$ water tree ${ }^{-1}$, during the growing season). Therefore, each block consisted of 24 plots (four main plots divided in two subplots) of three similar trees. Soil N fertilization was assigned to the main plots and foliar $\mathrm{N}$ sprays were applied to the subplots. The highest $\mathrm{N}$ fertilization to the soil $\left(100 \mathrm{~kg} \mathrm{ha}^{-1}\right)$ was set based on the recommended $\mathrm{N}$ fertilization for rainfed almond orchards in Portugal (LQARS 
Fig. 1 Mean air temperature and total precipitation observed in Portugal from 1931 to 2017. The 3 years of this experiment (2015, 2016, and 2017) are marked with white circles (adapted from IPMA 2017)

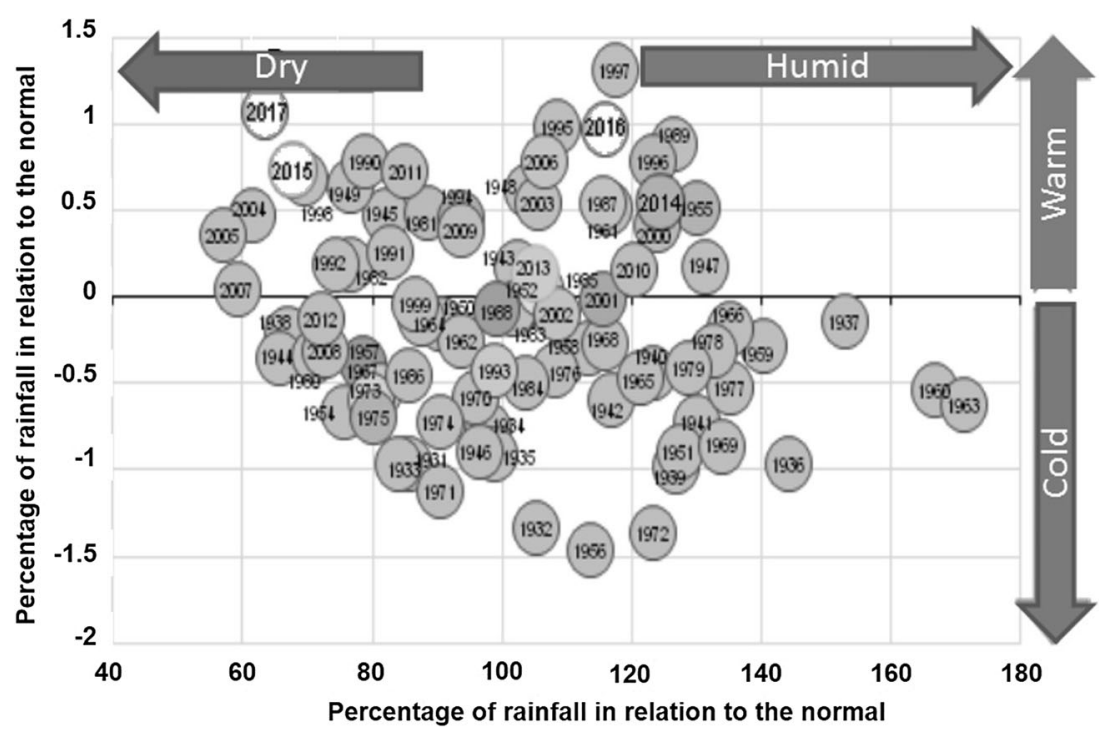

(Laboratório Químico Agricola Rebelo da Silva) 2006), and the reduced rates were applied to establish the minimum rate of this macronutrient. The $\mathrm{N}$ treatments were labeled as N0 (no soil $\mathrm{N}$ fertilizer), $\mathrm{N} 25$ (25 kg ha ${ }^{-1}$ in soil), $\mathrm{N} 50$ (50 kg ha in soil), $\mathrm{N} 100$ (100 kg ha ${ }^{-1}$ in soil), F0 (no foliar application of urea), and F3 (foliar application of urea). Soil N application occurred once a year (late in March, shortly after bloom), and foliar applications were performed two or three times during the growing season (May, July, and August 2015; and June, July, and September 2016; and May and July 2017, since an application was at post-harvest and the experiment ended after the third harvest). All treatments received soil and foliar phosphorus $\left(\mathrm{P}_{2} \mathrm{O}_{5}\right)$ and potassium $\left(\mathrm{K}_{2} \mathrm{O}\right)$ at the rate of $50 \mathrm{~kg} \mathrm{ha}^{-1}$ year $^{-1}$.

Every 3 years, the almond orchard was submitted to a more severe pruning. During this experiment, the almond trees were pruned more intensively in January 2016 and subjected to light pruning in 2015 and 2017. No phytosanitary treatments were applied during the experimental period.

\subsection{Data Collection}

During the experiment, measurements of leaf gas exchange, relative water content, and electrolyte leakage were realized at the harvest date (September). Leaves from around the canopy were collected to determine leaf photosynthetic pigments. Almond fruits were also harvested with a trunk shaker and the yield per tree was recorded. A subsample of fresh fruits was intended for laboratory analysis.

\subsection{Leaf Gas Exchange Measurements}

Leaf gas exchange measurements were performed on the uppermost fully expanded leaf from the middle of the canopy of three plants per treatment, by using an open portable Infrared
Gas Analyzer System (LCpro+, Hoddesdon, England) with a $2.5-\mathrm{cm}^{2}$ leaf chamber (ADC-PLC). The measurements were made in situ at midday (13.00-14.30 h), under a photosynthetic photon flux density (PPFD) always greater than $1500 \mu \mathrm{mol} \mathrm{m} \mathrm{m}^{-2} \mathrm{~s}^{-1}$. Net $\mathrm{CO}_{2}$ assimilation rate $(A$, $\left.\mu \mathrm{mol} \mathrm{CO}_{2} \mathrm{~m}^{-2} \mathrm{~s}^{-1}\right)$, stomatal conductance $\left(g_{\mathrm{s}}\right.$, mmol $\left.\mathrm{H}_{2} \mathrm{O} \mathrm{m}^{-2} \mathrm{~s}^{-1}\right)$, transpiration rate $(E$, mmol $\mathrm{H}_{2} \mathrm{O} \mathrm{m}^{-2} \mathrm{~s}^{-1}$ ), and the ratio of internal to atmospheric $\mathrm{CO}_{2}$ concentration $\left(C_{\mathrm{i}} / C_{\mathrm{a}}\right)$ were estimated from gas exchange measurements using the equations derived by von Caemmerer and Farquhar (1981). Intrinsic water-use efficiency (WUE) was determined by dividing $A$ by $g_{\mathrm{s}}\left(\mathrm{mmol} \mathrm{m} \mathrm{m}^{-2} \mathrm{~s}^{-1}\right)$ following Iacono et al. (1998).

\subsection{Relative Water Content and Electrolyte Leakage Determination}

For the determination of relative water content (RWC), one leaf per tree was immediately placed into air-tight containers. RWC was calculated according to the expression of Filella et al. (1998): RWC $(\%)=(F W-D W) /(T W-D W) \times 100$, where FW is the fresh weight $(\mathrm{g}), \mathrm{DW}$ is the dry weight $(\mathrm{g})$, after the leaves were dried at $70{ }^{\circ} \mathrm{C}$ to a constant weight, and TW is the fresh weight at full turgor $(\mathrm{g})$ after immersion of leaf petioles in distilled water for $24 \mathrm{~h}$ at $4{ }^{\circ} \mathrm{C}$ in the dark.

The membrane permeability of leaves was evaluated by electrolyte leakage (EL), as described by Lutts et al. (1996). Leaf discs ( $0.8 \mathrm{~cm}$ diameter), previously washed with deionized water to remove all surface-adhered electrolytes, were placed in tubes containing $10 \mathrm{ml}$ deionized water and incubated at $25^{\circ} \mathrm{C}$ on a shaker for $24 \mathrm{~h}$. After this period, the electrical conductivity of the bathing solution $\left(\mathrm{CE}_{1}\right)$ was determined, and the tubes were then autoclaved at $120{ }^{\circ} \mathrm{C}$ for $20 \mathrm{~min}$ and maintained at $25^{\circ} \mathrm{C}$. A new reading of electrical conductivity 
$\left(\mathrm{CE}_{2}\right)$ was done, and the EL was calculated as $\mathrm{EL}=\mathrm{CE}_{1} / \mathrm{CE}_{2}$ and expressed on a percentage basis.

\subsection{Photosynthetic Pigments in Leaves}

Quantification of photosynthetic pigments (chlorophyll $a$ [chl $a]$, chlorophyll $b[\mathrm{chl} b]$, total chlorophyll [chl $t]$, and total carotenoids [carot.]) was analyzed in leaf discs $(0.8 \mathrm{~cm}$ diameter), collected immediately after leaf gas exchange readings, frozen in liquid nitrogen, and stored at $-80{ }^{\circ} \mathrm{C}$ prior to analysis. Photosynthetic pigments were extracted in $80 \%$ acetone (v/v), according to Sesták et al. (1971) and Lichtenthaler (1987), for chlorophyll and total carotenoid determination, respectively.

\subsection{Yield and Fruit Quality Traits}

Almond fruits were collected per tree in September and weighed fresh. Almond yield $\left(\mathrm{tha}^{-1}\right)$ was determined for each treatment. Three samples of 50 fruits each were dried at room temperature for 1 month. After that, the mass of the nut and kernel were recorded and the number of fruits per kilogram was also determined as a measure of almond yield (Reidel et al. 2001).

\subsection{Statistical Analysis}

To analyze all data along the 3-year period of the experiment, repeated measures ANOVA with year of observation as a within-subject factor and soil and foliar $\mathrm{N}$ fertilization as between-group factors was performed. For each year, differences between soil $\mathrm{N}$ fertilization and foliar $\mathrm{N}$ fertilization were analyzed by a two-way ANOVA. Assumptions of normality and homogeneity of variance were tested with ShapiroWilk $W$ statistic and Levene's test, respectively. Mean differences were separated with the Tukey HSD test at a $5 \%$ level of significance. Principal component analysis (PCA) was used to get an overall view of the relationship between all measured parameters.

Statistical analyses were handled using JMP software 7.0 (SAS Institute Inc., Cary, NC, USA). Multivariate analysis with PCA was performed using Statistica 8 (StatSoft Inc.) program.

\section{Results}

\subsection{Leaf Gas Exchange Parameters}

Leaf gas exchange parameters varied significantly $(p<0.05)$ during the experimental period (Table 1). Significantly higher $E, g_{\mathrm{s}}, C_{\mathrm{i}} / C_{\mathrm{a}}$, and $A$ were observed in the second year, 2016, while $A / g_{\mathrm{s}}$ presented an inverse behavior, peaking in 2015 and
2017 (Table 2). Interestingly, there were no significant differences in most of the leaf gas exchange parameters between the first and third years of the experiment (Table 2). In all years of the experiment (Table 3), the soil fertilization tended to increase $E, g_{\mathrm{s}}$, and $A$ in relation to the N0 treatment, but the same trend was not observed with $A / g_{\mathrm{s}}$. In fact, only the $\mathrm{N} 25$ treatment $\left(25 \mathrm{~kg} \mathrm{~N} \mathrm{ha}^{-1}\right)$ allowed an increase in the $A /$ $g_{\mathrm{s}}$ values, independently of the year, in relation to the N0 treatment. In 2015 and 2016, maximum $E, g_{\mathrm{s}}$ and $A$ values were achieved with $\mathrm{N}$ rate of $25 \mathrm{~kg} \mathrm{~N} \mathrm{ha}^{-1}$, while in 2017 , there was not a clear pattern. Foliar sprays of $\mathrm{N}$ did not influence any of the leaf gas exchange parameters. With respect to the interaction, none of the combined effects of soil and foliar fertilization was significant $(p>0.05)$ in all leaf gas exchange parameters in each year.

PCA analysis performed with gas exchange parameters (Fig. 2) showed that the two first component axes accounted about $50 \%$ of the variability of the data set. In this case, $A, g_{\mathrm{s}}$, and $E$ presented the same variance and were strongly and positively correlated. In turn, there was an inverse effect of $A / g_{\mathrm{s}}$ and $C_{\mathrm{i}} / C_{\mathrm{a}}$. The 3 years of the experiment were very different, with 2016 showed an opposite behavior in relation to 2015 and 2017. The N0, N100, and F3 treatments were located on the left side, while the N25, N50, and F0 treatments were located on the right side, forming two well-separated groups, resulted in a clear similarity in the physiological behavior of almond plants subjected to such $\mathrm{N}$ treatments.

\subsection{Relative Water Content and Electrolyte Leakage}

The leaf relative water content (RWC) varied significantly with year and foliar fertilization (Table 1). Generally, the RWC values followed the same trend as leaf gas exchange parameters (Table 2), being higher in 2016 (77.6\% against $72.2 \%$ in 2015 and $73.6 \%$ in 2017). In each year of the experiment, the application of $\mathrm{N}$ to the soil did not significantly change RWC ( $p>0.05)$ (Fig. 3). In 2015 and 2016, the differences between both treatments of foliar $\mathrm{N}$ fertilization ( $\mathrm{F} 0$ and F3) were not statistically significant. However, in 2017, leaf RWC was significantly higher in the absence of foliar application of N (Fig. 3).

In terms of the influence of each factor on electrolyte leakage (EL), differences were only observed among years (Table 1). Overall, 2015 had the highest EL (37.0\%) among the 3 years of study (26.8\% in 2017 and $14.3 \%$ in 2016). Soil and foliar N application did not influence annual EL values (Fig. 4).

\subsection{Photosynthetic Pigments}

The content of photosynthetic pigments was significantly affected $(p<0.001)$ by year of the experiment (Table 1$)$, but there was not a consistent trend. Chl $a, \operatorname{chl} b, \operatorname{chl} t$, and the ratio chl $t /$ carot presented a clear accumulation of its content in 
Table 1 Results from repeated measures ANOVA of the effects of soil and foliar $\mathrm{N}$ fertilization throughout time (year) on leaf gas exchange parameters $\left(E, g_{\mathrm{s}}, C_{\mathrm{i}} /\right.$ $\left.C_{\mathrm{a}}, A, A / g_{\mathrm{s}}\right), \mathrm{RWC}$, EL, photosynthetic pigments (chl $a, \operatorname{chl} b$, chl $t, \operatorname{chl} a / \operatorname{chl} b$, carot, chl $t /$ carot), yield, and its components (almonds per kg, nut, and kernel mass)

\begin{tabular}{lllll}
\hline & Year & Year $\times$ soil & Year $\times$ foliar & Year $\times$ soil $\times$ foliar \\
\hline$E\left(\mathrm{mmol} \mathrm{m}^{-2} \mathrm{~s}^{-1}\right)$ & 0.000 & 0.559 & 0.260 & 0.878 \\
$g_{\mathrm{s}}\left(\mathrm{mmol} \mathrm{m}^{-2} \mathrm{~s}^{-1}\right)$ & 0.000 & 0.569 & 0.190 & 0.782 \\
$C_{\mathrm{i}} / C_{\mathrm{a}}\left(\mu \mathrm{mol} \mathrm{mol}^{-1}\right)$ & 0.000 & 0.952 & 0.117 & 0.201 \\
$A\left(\mu \mathrm{mol} \mathrm{m}^{-2} \mathrm{~s}^{-1}\right)$ & 0.000 & 0.684 & 0.205 & 0.972 \\
$A / g_{\mathrm{s}}\left(\mu \mathrm{mol} \mathrm{mol}^{-1}\right)$ & 0.000 & 0.431 & 0.407 & 0.208 \\
$\mathrm{RWC}(\%)$ & 0.000 & 0.362 & 0.017 & 0.341 \\
EL $(\%)$ & 0.000 & 0.794 & 0.053 & 0.393 \\
Chl $a\left(\mathrm{mg} \mathrm{g}^{-1}\right)$ & 0.000 & 0.472 & 0.594 & 0.269 \\
Chl $b\left(\mathrm{mg} \mathrm{g}^{-1}\right)$ & 0.000 & 0.913 & 0.988 & 0.235 \\
Chl $t\left(\mathrm{mg} \mathrm{g}^{-1}\right)$ & 0.000 & 0.929 & 0.344 & 0.445 \\
Chl $\left.a / \mathrm{chl} b^{-1}\right)$ & 0.000 & 0.245 & 0.746 & 0.773 \\
Carot $\left(\mathrm{mg} \mathrm{g}^{-1}\right)$ & 0.016 & 0.574 & 0.979 & 0.967 \\
Chl $\left.t / \mathrm{carot}^{-1}\right)$ & 0.000 & 0.918 & 0.997 & 0.212 \\
Yield $\left(\mathrm{t} \mathrm{ha}{ }^{-1}\right)$ & 0.000 & 0.000 & 0.160 & 0.442 \\
Almonds per kg & 0.000 & 0.412 & 0.140 & 0.406 \\
Nut mass $(\mathrm{g})$ & 0.000 & 0.610 & 0.261 & 0.676 \\
Kernel mass $(\mathrm{g})$ & 0.000 & 0.834 & 0.175 & 0.636 \\
\hline
\end{tabular}

Only the within-subjects are shown. Significant differences are marked in italics the third year of the experiment (2017). On the contrary, the highest chl $a / \mathrm{chl} b$ ratio and carotenoids were observed in 2015 (Table 2). When looking to the effect of soil and foliar

Table 2 Values (mean \pm standard error) of leaf gas exchange parameters $\left(E, g_{\mathrm{s}}, C_{\mathrm{i}} / C_{\mathrm{a}}, A, A / g_{\mathrm{s}}\right), \mathrm{RWC}, \mathrm{EL}$, photosynthetic pigments (chl $a, \operatorname{chl} b, \operatorname{chl} t, \operatorname{chl} a / \operatorname{chl} b$, carot, chl $t /$ carot), yield, and its components (almonds per $\mathrm{kg}$, nut, and kernel mass). For each parameter, different letters indicate significant differences $(p<0.05)$ according to Tukey's HSD test

\begin{tabular}{|c|c|c|c|}
\hline & 2015 & 2016 & 2017 \\
\hline$E\left(\mathrm{mmol} \mathrm{m}^{-2} \mathrm{~s}^{-1}\right)$ & $1.08 \pm 0.15 \mathrm{a}$ & $2.15 \pm 0.20 \mathrm{~b}$ & $1.17 \pm 0.13 \mathrm{a}$ \\
\hline$g_{\mathrm{s}}\left(\mathrm{mmol} \mathrm{m} \mathrm{m}^{-2} \mathrm{~s}^{-1}\right)$ & $18.97 \pm 2.83 \mathrm{a}$ & $45.88 \pm 4.95 \mathrm{~b}$ & $26.80 \pm 3.33 \mathrm{a}$ \\
\hline$C_{\mathrm{i}} / C_{\mathrm{a}}\left(\mu \mathrm{mol} \mathrm{\textrm {mol } ^ { - 1 } )}\right.$ & $0.49 \pm 0.02 \mathrm{a}$ & $0.61 \pm 0.01 \mathrm{~b}$ & $0.49 \pm 0.01 \mathrm{a}$ \\
\hline$A\left(\mu \mathrm{mol} \mathrm{m}{ }^{-2} \mathrm{~s}^{-1}\right)$ & $1.80 \pm 0.31 \mathrm{a}$ & $3.22 \pm 0.35 \mathrm{~b}$ & $2.57 \pm 0.31 \mathrm{~b}$ \\
\hline$A / g_{\mathrm{s}}\left(\mu \mathrm{mol} \mathrm{mol}{ }^{-1}\right)$ & $111.56 \pm 4.95 b$ & $77.28 \pm 2.12 \mathrm{a}$ & $109.53 \pm 2.65 b$ \\
\hline RWC (\%) & $72.22 \pm 0.63 \mathrm{a}$ & $77.63 \pm 0.51 \mathrm{~b}$ & $73.61 \pm 0.86 \mathrm{a}$ \\
\hline EL $(\%)$ & $37.05 \pm 0.65 \mathrm{c}$ & $14.30 \pm 0.34 \mathrm{a}$ & $26.80 \pm 0.88 \mathrm{~b}$ \\
\hline $\mathrm{Chl} a\left(\mathrm{mg} \mathrm{g}^{-1}\right)$ & $2.56 \pm 0.09 \mathrm{a}$ & $2.60 \pm 0.08 \mathrm{a}$ & $3.53 \pm 0.10 b$ \\
\hline $\mathrm{Chl} b\left(\mathrm{mg} \mathrm{g}^{-1}\right)$ & $0.92 \pm 0.06 \mathrm{a}$ & $1.23 \pm 0.05 \mathrm{~b}$ & $1.34 \pm 0.10 \mathrm{~b}$ \\
\hline $\mathrm{Chl} t\left(\mathrm{mg} \mathrm{g}^{-1}\right)$ & $3.41 \pm 0.13 \mathrm{a}$ & $3.87 \pm 0.14 \mathrm{a}$ & $5.53 \pm 0.20 \mathrm{~b}$ \\
\hline Chl $a / \operatorname{chl} b$ & $2.83 \pm 0.06 \mathrm{c}$ & $2.08 \pm 0.07 \mathrm{a}$ & $2.44 \pm 0.11 \mathrm{~b}$ \\
\hline Carot $\left(\mathrm{mg} \mathrm{g}^{-1}\right)$ & $0.63 \pm 0.02 \mathrm{~b}$ & $0.53 \pm 0.02 \mathrm{a}$ & $0.56 \pm 0.02 \mathrm{a}$ \\
\hline Chl $t /$ carot & $5.35 \pm 0.09 \mathrm{a}$ & $7.43 \pm 0.37 b$ & $10.63 \pm 0.81 \mathrm{c}$ \\
\hline Yield ( $\left.\mathrm{t} \mathrm{ha}^{-1}\right)$ & $4.10 \pm 0.21 \mathrm{~b}$ & $0.06 \pm 0.01 \mathrm{a}$ & $3.68 \pm 0.21 \mathrm{~b}$ \\
\hline Almonds per kg & $227 \pm 9 \mathrm{a}$ & $221 \pm 4 \mathrm{a}$ & $358 \pm 5 \mathrm{~b}$ \\
\hline Nut mass (g) & $4.64 \pm 0.16 b$ & $4.70 \pm 0.09 b$ & $2.89 \pm 0.04 \mathrm{a}$ \\
\hline Kernel mass (g) & $1.08 \pm 0.03 b$ & $1.32 \pm 0.02 \mathrm{c}$ & $0.89 \pm 0.01 \mathrm{a}$ \\
\hline
\end{tabular}

$\mathrm{N}$ fertilization in each year (Table 4), there was a lack of significant influence of both factors in the third year of the experiment. The $\mathrm{N}$ soil fertilization influenced the majority of photosynthetic pigments in 2015 and 2016, except the chl a/ chl $b$ and chl $t /$ carot ratios. In general, any application of $\mathrm{N}$ to the soil promoted the formation of $\operatorname{chl} a, \operatorname{chl} b, \operatorname{chl} t$, and carot when compared with the control treatment (N0) and the effect was most evident when $\mathrm{N}$ fertilization is used at the rate $100 \mathrm{~kg} \mathrm{ha}^{-1}$. In turn, application of $\mathrm{N}$ by foliar spray did not significantly increase the content of such photosynthetic pigments. The effect of $\mathrm{N}$ foliar fertilization only was significant on the chl $a / \mathrm{chl} b$ and chl $t /$ carot ratios determined in 2015, but no clear trend was visible. For all photosynthetic pigments, the interaction effects of soil and foliar $\mathrm{N}$ fertilization were not significant $(p>0.05)$.

The PCA analysis of the photosynthetic pigments data is presented in Fig. 5. Loading plot for the 1st and 2nd axes explained $28.0 \%$ and $18.6 \%$ of the total variance, respectively. According to this analysis, chl $a / \mathrm{chl} b$ and chl $t /$ carot ratios were negatively correlated, while the photosynthetic pigments $\operatorname{chl} a, \operatorname{chl} b$, and chl $t$ were more highly clustered, reflecting the close relationship between them. This analysis also showed a contrasting separation between the 3 years of the study. In terms of fertilization, there was a similarity between $\mathrm{N}$ soil fertilization at the rates $25 \mathrm{~kg} \mathrm{ha}^{-1}(\mathrm{~N} 25)$ and no $\mathrm{N}$ foliar (F0) fertilization.

\subsection{Almond Yield and Fruit Quality Traits}

On average, almond yield was higher in the first and third years of the study, respectively, reflecting a strong 
Table 3 Transpiration rate $(E)$, stomatal conductance $\left(g_{\mathrm{s}}\right)$, ratio of internal to atmospheric $\mathrm{CO}_{2}\left(C_{\mathrm{i}} / C_{\mathrm{a}}\right)$, net $\mathrm{CO}_{2}$ assimilation rate $(A)$, and water-use efficiency $\left(A / g_{s}\right)$ of almond leaves in the 2015-2017 period. Data are means \pm standard error. Following two-way ANOVA, for each parameter, different lowercase letters indicate significant differences $(p<0.05)$ among $\mathrm{N}$ soil (N0, N25, N50, and N100) and capital letters represent significant differences between $\mathrm{N}$ foliar (F0 and F3) treatments, according to Tukey's HSD test

\begin{tabular}{|c|c|c|c|c|c|c|c|}
\hline \multirow{2}{*}{$\frac{\text { Year }}{2015}$} & \multicolumn{2}{|c|}{ Fertilization } & \multirow{2}{*}{$\frac{E\left(\mathrm{mmol} \mathrm{m} \mathrm{m}^{-2} \mathrm{~s}^{-1}\right)}{0.75 \pm 0.06 \mathrm{a}}$} & \multirow{2}{*}{$\frac{g_{\mathrm{s}}\left(\mathrm{mmol} \mathrm{m} \mathrm{m}^{-2} \mathrm{~s}^{-1}\right)}{12.02 \pm 1.09 \mathrm{a}}$} & \multirow{2}{*}{$\frac{C_{\mathrm{i}} / C_{\mathrm{a}}\left(\mu \mathrm{mol} \mathrm{\textrm {mol } ^ { - 1 } )}\right.}{0.45 \pm 0.02 \mathrm{a}}$} & \multirow{2}{*}{$\frac{A\left(\mu \mathrm{mol} \mathrm{m} \mathrm{m}^{-2} \mathrm{~s}^{-1}\right)}{1.37 \pm 0.13 \mathrm{a}}$} & \multirow{2}{*}{$\frac{A / g_{\mathrm{s}}\left(\mu \mathrm{mol} \mathrm{\textrm {mol } ^ { - 1 }}\right)}{115.31 \pm 6.28 \mathrm{a}}$} \\
\hline & Soil & No & & & & & \\
\hline & & N25 & $1.46 \pm 0.29 \mathrm{a}$ & $26.56 \pm 5.56 \mathrm{a}$ & $0.46 \pm 0.05 \mathrm{a}$ & $3.10 \pm 0.74 \mathrm{a}$ & $124.69 \pm 3.61 \mathrm{a}$ \\
\hline & & N50 & $1.09 \pm 0.33 \mathrm{a}$ & $19.40 \pm 6.08 \mathrm{a}$ & $0.49 \pm 0.04 \mathrm{a}$ & $2.18 \pm 0.74 \mathrm{a}$ & $105.42 \pm 8.46 \mathrm{a}$ \\
\hline & & N100 & $1.17 \pm 0.43 \mathrm{a}$ & $17.89 \pm 7.54 \mathrm{a}$ & $0.52 \pm 0.06 \mathrm{a}$ & $1.93 \pm 0.85 \mathrm{a}$ & $99.29 \pm 14.31 \mathrm{a}$ \\
\hline & Foliar & F0 & $1.07 \pm 0.18 \mathrm{~A}$ & $19.41 \pm 3.61 \mathrm{~A}$ & $0.44 \pm 0.02 \mathrm{~A}$ & $2.28 \pm 0.40 \mathrm{~A}$ & $118.59 \pm 5.26 \mathrm{~A}$ \\
\hline & & F3 & $1.17 \pm 0.24 \mathrm{~A}$ & $18.52 \pm 4.52 \mathrm{~A}$ & $0.52 \pm 0.03 \mathrm{~A}$ & $2.01 \pm 0.57 \mathrm{~A}$ & $101.87 \pm 7.70 \mathrm{~A}$ \\
\hline & & \multicolumn{6}{|c|}{ Two-way ANOVA } \\
\hline & & Soil (S) & 0.344 & 0.268 & 0.686 & 0.283 & 0.183 \\
\hline & & Foliar (F) & 0.893 & 0.860 & 0.058 & 0.654 & 0.079 \\
\hline & & $\mathrm{S} \times \mathrm{F}$ & 0.096 & 0.056 & 0.189 & 0.078 & 0.076 \\
\hline \multirow[t]{10}{*}{2016} & Soil & N0 & $1.78 \pm 0.29 \mathrm{a}$ & $35.24 \pm 6.30 \mathrm{a}$ & $0.61 \pm 0.02 \mathrm{a}$ & $2.79 \pm 0.52 \mathrm{a}$ & $77.14 \pm 3.73 \mathrm{a}$ \\
\hline & & N25 & $2.48 \pm 0.37 \mathrm{a}$ & $55.51 \pm 9.45 \mathrm{a}$ & $0.59 \pm 0.02 \mathrm{a}$ & $4.42 \pm 0.65 \mathrm{a}$ & $82.65 \pm 4.67 \mathrm{a}$ \\
\hline & & N50 & $2.26 \pm 0.36 \mathrm{a}$ & $48.15 \pm 8.93 \mathrm{a}$ & $0.63 \pm 0.03 \mathrm{a}$ & $3.50 \pm 0.60 \mathrm{a}$ & $73.14 \pm 6.27 \mathrm{a}$ \\
\hline & & N100 & $1.70 \pm 0.50 \mathrm{a}$ & $44.61 \pm 14.11 \mathrm{a}$ & $0.62 \pm 0.02 \mathrm{a}$ & $3.30 \pm 0.94 \mathrm{a}$ & $75.98 \pm 4.29 \mathrm{a}$ \\
\hline & Foliar & F0 & $2.18 \pm 0.74 \mathrm{~A}$ & $51.13 \pm 6.53 \mathrm{~A}$ & $0.61 \pm 0.01 \mathrm{~A}$ & $3.91 \pm 0.47 \mathrm{~A}$ & $77.03 \pm 3.29 \mathrm{~A}$ \\
\hline & & F3 & $1.96 \pm 0.30 \mathrm{~A}$ & $40.63 \pm 7.39 \mathrm{~A}$ & $0.61 \pm 0.01 \mathrm{~A}$ & $3.10 \pm 0.50 \mathrm{~A}$ & $77.42 \pm 3.54 \mathrm{~A}$ \\
\hline & & \multicolumn{6}{|c|}{ Two-way ANOVA } \\
\hline & & Soil (S) & 0.478 & 0.502 & 0.586 & 0.399 & 0.642 \\
\hline & & Foliar (F) & 0.538 & 0.275 & 0.955 & 0.238 & 0.941 \\
\hline & & $\mathrm{S} \times \mathrm{F}$ & 0.274 & 0.140 & 0.906 & 0.245 & 0.853 \\
\hline \multirow[t]{10}{*}{2017} & Soil & No & $1.01 \pm 0.17 \mathrm{a}$ & $22.10 \pm 4.36 \mathrm{a}$ & $0.49 \pm 0.03 \mathrm{a}$ & $2.54 \pm 0.55 \mathrm{a}$ & $111.68 \pm 6.23 \mathrm{a}$ \\
\hline & & N25 & $1.08 \pm 0.21 \mathrm{a}$ & $24.91 \pm 5.28 \mathrm{a}$ & $0.45 \pm 0.02 \mathrm{a}$ & $3.00 \pm 0.63 \mathrm{a}$ & $121.03 \pm 4.32 \mathrm{a}$ \\
\hline & & N50 & $1.39 \pm 0.30 \mathrm{a}$ & $32.40 \pm 7.55 \mathrm{a}$ & $0.51 \pm 0.02 \mathrm{a}$ & $3.46 \pm 0.83 \mathrm{a}$ & $105.11 \pm 5.51 \mathrm{a}$ \\
\hline & & N100 & $1.90 \pm 0.35 \mathrm{a}$ & $27.80 \pm 9.41 \mathrm{a}$ & $0.50 \pm 0.02 \mathrm{a}$ & $2.89 \pm 0.89 \mathrm{a}$ & $108.14 \pm 5.19 \mathrm{a}$ \\
\hline & Foliar & F0 & $1.38 \pm 0.16 \mathrm{~A}$ & $33.18 \pm 4.27 \mathrm{~A}$ & $0.48 \pm 0.02 \mathrm{~A}$ & $3.68 \pm 0.40 B$ & $112.96 \pm 4.23 \mathrm{~A}$ \\
\hline & & F3 & $0.95 \pm 0.19 \mathrm{~A}$ & $20.43 \pm 4.55 \mathrm{~A}$ & $0.50 \pm 0.02 \mathrm{~A}$ & $2.26 \pm 0.51 \mathrm{~A}$ & $110.02 \pm 3.78 \mathrm{~A}$ \\
\hline & & \multicolumn{6}{|c|}{ Two-way ANOVA } \\
\hline & & Soil (S) & 0.710 & 0.689 & 0.299 & 0.810 & 0.257 \\
\hline & & Foliar $(\mathrm{F})$ & 0.099 & 0.057 & 0.534 & 0.049 & 0.611 \\
\hline & & $\mathrm{S} \times \mathrm{F}$ & 0.211 & 0.246 & 0.656 & 0.295 & 0.633 \\
\hline
\end{tabular}

Significant differences are marked in italics

variability among years $(p<0.001)$, especially in 2016 (Tables 1 and 2). Almond yield also was differently influenced by $\mathrm{N}$ soil fertilization (Table 1). Considering the effect of soil and foliar $\mathrm{N}$ fertilization in each year, any $\mathrm{N}$ soil treatment tended to increase almond production $(p<0.001)$ in relation to the control treatment (N0) especially in 2015 and 2017 (Fig. 6). In 2015, the highest almond productions were obtained in the N100 treatment $\left(5.62 \pm 0.46 \mathrm{tha}^{-1}\right)$, about $114 \%$ more than the N0 treatment, and in the N50 treatment $\left(4.49 \pm 0.36 \mathrm{t} \mathrm{ha}^{-1}\right), 62 \%$ more than the N0 treatment. In the last year of the study (2017), the greatest production was obtained with an application of $25 \mathrm{~kg} \mathrm{~N} \mathrm{ha}^{-1}$ to the soil (N25), with $4.52 \pm$
$0.34 \mathrm{t} \mathrm{ha}^{-1}$, which was about $60 \%$ higher when compared with the N0 treatment. In turn, the minimum yield in 2015 and 2017 was recorded in the N0 treatment $(2.63 \pm$ $0.23 \mathrm{t} \mathrm{ha}^{-1}$ and $2.85 \pm 0.36 \mathrm{t} \mathrm{ha}^{-1}$, respectively). In 2016, almond yield was minimal $\left(0.06 \pm 0.01 \mathrm{t} \mathrm{ha}^{-1}\right)$ indicating a clear pattern of alternate bearing. After the 3-year experimental period, almond yield increased with the application of $\mathrm{N}$ to the soil $(p=0.0001)$, representing a $50-65 \%$ increase with respect to the N0 treatment (Fig. 6). Foliar N application failed to improve $(p>0.05)$ almond yield in any of the years of the study and at the end of the 3-year period. The combination of soil and foliar $\mathrm{N}$ fertilization did not produce significant differences on almond yield (Fig. 6). 
Fig. 2 PCA loading plot of leaf gas exchange parameters measured in almond trees submitted to $\mathrm{N}$ soil $(\mathrm{N} 0, \mathrm{~N} 25$, $\mathrm{N} 50$, and $\mathrm{N} 100)$ and $\mathrm{N}$ foliar (F0 and F3) fertilization throughout 2015-2017

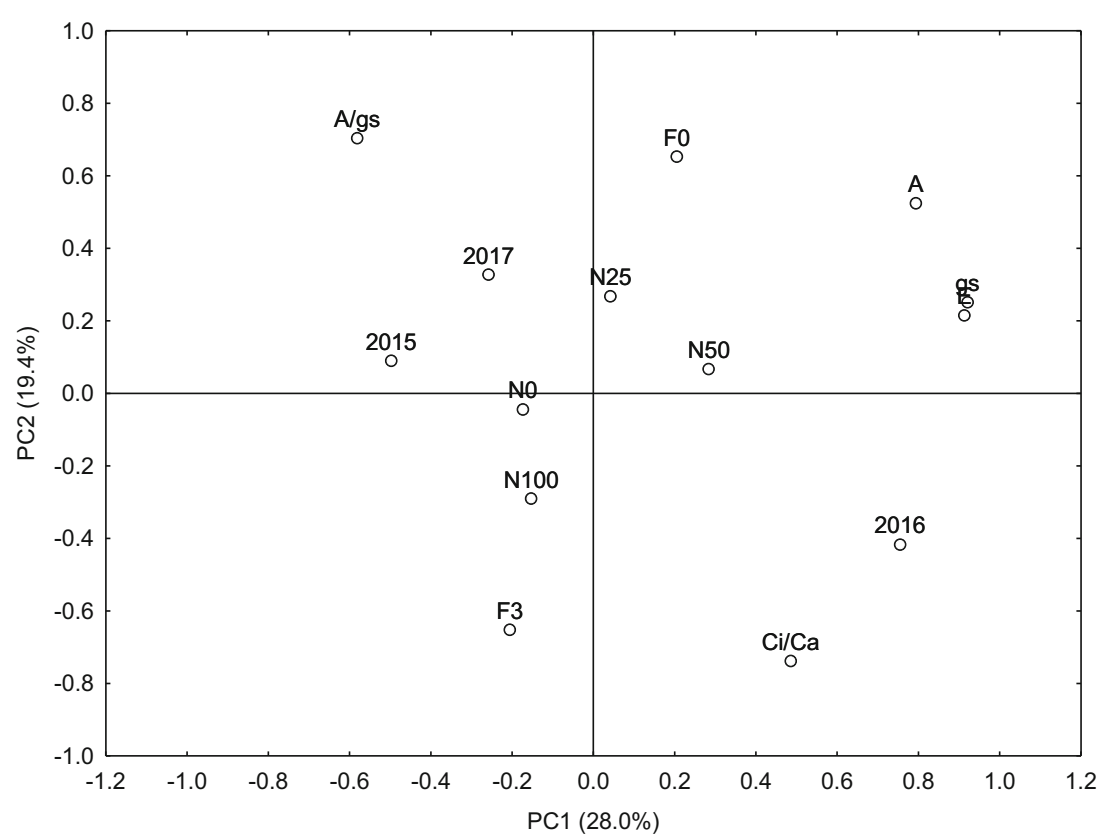

The number of almonds by kilogram (Table 1), used as a measure of almond yield and almond dimensions, was more dependent on the year of the study $(p<0.001)$ than the soil or foliar $\mathrm{N}$ fertilization $(p>0.05)$. The average number of almonds by kilogram was higher in $2017(358 \pm 5)$ and decreased by $36 \%$ in $2015(227 \pm 9)$ and 38\% in $2016(221 \pm$ 4). When data were analyzed separately for each year, the number of almonds per kilogram was influenced neither by soil fertilization nor by the application of $\mathrm{N}$ via foliar spray. No significant interactions were also found for this parameter.

Regarding the nut mass (shell + kernel), there was a significant variation among years $(p<0.001)$ displaying an inverse behavior than those observed with almonds per kilogram (Table 2). The highest nut mass was observed in the second year of the study $(4.73 \pm 0.03 \mathrm{~g})$, distinct from those determined in the first $(4.57 \pm 0.03 \mathrm{~g})$ and the third years $(2.93 \pm$ $0.01 \mathrm{~g})$. Similarly, the kernel mass also presented the same trend $(p<0.001)$; i.e., the second year of the study was responsible for the highest kernel mass $(1.30 \pm 0.04 \mathrm{~g})$, followed by the first year $(1.08 \pm 0.01 \mathrm{~g})$ and the third year $(0.91 \pm 0.04 \mathrm{~g})$. Soil and foliar $\mathrm{N}$ applications did not significantly affect the nut and kernel mass in any of the individual years (Table 5). For both parameters, the interaction effects between soil and foliar N application were not significant $(p>0.05)$.

The PCA determined strong differences in almond yield and fruit quality parameters among years of study. The first principal component (PC1) accounted for $33.7 \%$ of the total variation, and the second component (PC2) for $16.0 \%$ of the variation (Fig. 7). The third year of the study (2017) formed a separated group with an inverse position to 2016 and 2015 and is mostly associated with yield and its component (number of almonds per kilogram). On the other hand, 2015 and 2016 were more associated with fruit quality traits (kernel and nut mass). Concerning $\mathrm{N}$ soil and foliar fertilization, F3, N50, and $\mathrm{N} 100$ were displayed on the positive side and were associated with yield, while N0, N25, and F0 were more associated with fruit characteristics.

\section{Discussion}

Production of the rainfed almond orchard varied considerably during the experiment (Tables 1 and 2 and Fig. 6), for climatic (unsuitable precipitation observed in 2016) and botanical reasons (alternate bearing behavior of almond trees). The occurrence of the later phenomenon is highly dependent on the nutritional status of the tree, and $\mathrm{N}$ is recognized as the most important nutrient for reducing the negative impacts of alternate bearing (El-Motaium et al. 2019). In each year of the experiment and after three consecutive years, soil application of $\mathrm{N}$ improved significantly almond yield, even in the second year of the study (2016), when the yield was very low (Fig. 6). The beneficial effect of soil $\mathrm{N}$ fertilization in reducing the severity of alternate bearing has also been documented in other tree species, such as mango (El-Motaium et al. 2019) and avocado (Lovatt 2001). An increase in production following application of $\mathrm{N}$ to the soil has been observed in irrigated almonds (Weinbaum et al. 1994; Muhammad et al. 2018) as well as in other tree crops, such as chestnut (Rodrigues et al. 2020). The mechanism by which $\mathrm{N}$ increases yield is that deciduous trees like almonds use $\mathrm{N}$ and carbohydrates applied in the previous year for new growth in the present growing season (Bi et al. 2004). Unlike soil $\mathrm{N}$ fertilization, foliar supplementation with the same nutrient did not enhance almond 

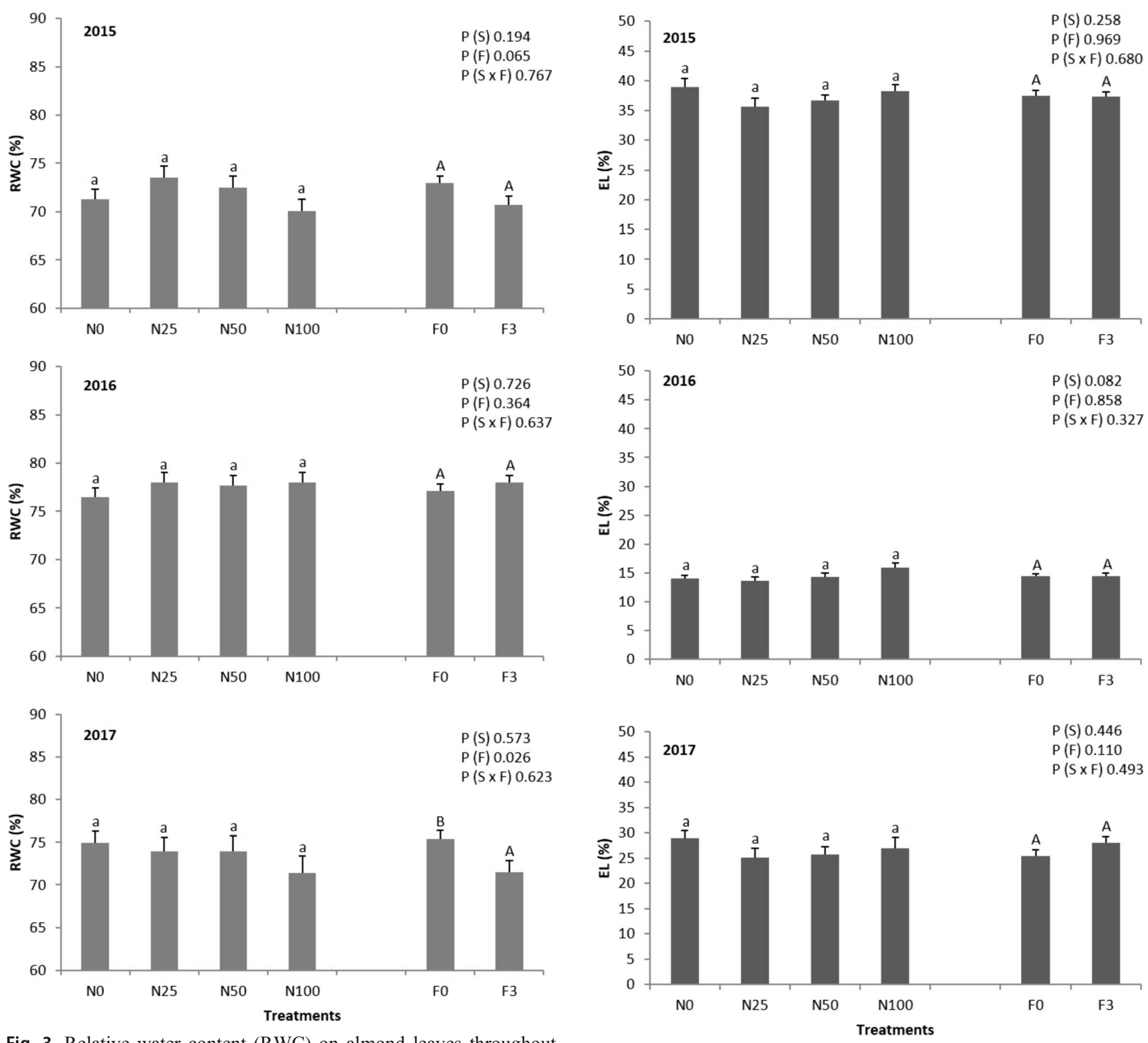

Fig. 3 Relative water content (RWC) on almond leaves throughout 2015-2017. $P$ represents the probability associated with N soil (N0, $\mathrm{N} 25, \mathrm{~N} 50$, and N100) and N foliar (F0 and F3) fertilization. Data are means \pm standard error. Different lowercase letters indicate significant differences $(p<0.05)$ among $\mathrm{N}$ soil $(\mathrm{N} 0, \mathrm{~N} 25, \mathrm{~N} 50$, and $\mathrm{N} 100)$, and capital letters represent significant differences between $\mathrm{N}$ foliar (F0 and F3) treatments, according to Tukey's HSD test

yield (Fig. 6). This result contradicts the general consensus that foliar sprays of $\mathrm{N}$ as supplementary to soil fertilization may help in maximizing the $\mathrm{N}$ uptake for better crop production and minimizing $\mathrm{N}$ losses (Amiri et al. 2008). As pointed out by Rodrigues et al. (2006), plants tended to respond to the $\mathrm{N}$ fertilization with an increase in yield and leaf $\mathrm{N}$ content. As such, the no yield response of almond trees with leaf $\mathrm{N}$ sprays can be explained by the null effect of this type of fertilization on leaf N content (Regni and Proietti 2019). According to the results of Arrobas et al. (2019) for the same conditions in which this study was carried out, the $\mathrm{N}$ concentration of leaves

Fig. 4 Electrolyte leakage (EL) on almond leaves throughout 20152017. Data are means \pm standard error. Different lowercase letters indicate significant differences $(p<0.05)$ among $\mathrm{N}$ soil $(\mathrm{N} 0, \mathrm{~N} 25, \mathrm{~N} 50$, and $\mathrm{N} 100$ ), and capital letters represent significant differences between $\mathrm{N}$ foliar (F0 and F3) treatments, according to Tukey's HSD test

remained relatively constant between foliar and no foliar $\mathrm{N}$ fertilization, further suggesting that it is not necessary to combine soil and foliar $\mathrm{N}$ fertilization to achieve high almond yield. In this particular situation, the amount of $\mathrm{N}$ required for almond production seems to be completely supplied from application of $\mathrm{N}$ to the soil. In most fruit trees, fruit size tends to decrease in heavy crop years (Gunes et al. 2010) and our results proved it (Table 5). Famiani et al. (2000), in chestnut; Gunes et al. (2010), in pistachio; Muhammad et al. (2018), in almond; and Neilsen et al. (2009), in apple, also reported that an increase in the number of fruits per tree is associated with a decrease in fruit weight. In many studies, it has been reported 
Table 4 Concentration of photosynthetic pigments $(\operatorname{chl} a, \operatorname{chl} b, \operatorname{chl} t$, chl $a /$ chl $b$, carot, chl $t /$ carot) of almond leaves in the 2015-2017 period. Data are means \pm standard error. Following two-way ANOVA, for each parameter, different lowercase letters indicate significant differences $(p<0.05)$ among $\mathrm{N}$ soil $(\mathrm{N} 0, \mathrm{~N} 25, \mathrm{~N} 50$, and N100) and capital letters represent significant differences between $\mathrm{N}$ foliar (F0 and $\mathrm{F} 3$ ) treatments according to Tukey's HSD test

\begin{tabular}{|c|c|c|c|c|c|c|c|}
\hline Year & Treatments & Chl $a\left(\mathrm{mg} \mathrm{g}^{-1}\right)$ & $\mathrm{Chl} b\left(\mathrm{mg} \mathrm{g}^{-1}\right)$ & $\mathrm{Chl} t\left(\mathrm{mg} \mathrm{g}^{-1}\right)$ & $\mathrm{Chl} a / \operatorname{chl} b$ & Carot $\left(\mathrm{mg} \mathrm{g}^{-1}\right)$ & Chl $t /$ carot \\
\hline 2015 & N0 & $2.33 \pm 0.16 a$ & $0.83 \pm 0.05 a$ & $3.16 \pm 0.21 a$ & $2.80 \pm 0.06 \mathrm{a}$ & $0.59 \pm 0.03 a$ & $5.35 \pm 0.10 \mathrm{a}$ \\
\hline \multirow[t]{3}{*}{ Soil } & N25 & $2.40 \pm 0.14 a b$ & $0.86 \pm 0.06 a b$ & $3.26 \pm 0.19 a b$ & $2.82 \pm 0.07 \mathrm{a}$ & $0.60 \pm 0.03 a b$ & $5.54 \pm 0.15 \mathrm{a}$ \\
\hline & N50 & $2.67 \pm 0.13 a b$ & $0.96 \pm 0.05 a b$ & $3.63 \pm 0.18 a b$ & $2.81 \pm 0.06 \mathrm{a}$ & $0.64 \pm 0.03 a b$ & $5.68 \pm 0.11 \mathrm{a}$ \\
\hline & N100 & $2.93 \pm 0.15 b$ & $1.04 \pm 0.06 b$ & $3.97 \pm 0.21 b$ & $2.85 \pm 0.07 \mathrm{a}$ & $0.71 \pm 0.03 b$ & $5.57 \pm 0.12 \mathrm{a}$ \\
\hline \multirow[t]{6}{*}{ Foliar } & F0 & $2.55 \pm 0.09 \mathrm{~A}$ & $0.94 \pm 0.04 \mathrm{~A}$ & $3.49 \pm 0.13 \mathrm{~A}$ & $2.73 \pm 0.04 \mathrm{~A}$ & $0.61 \pm 0.02 \mathrm{~A}$ & $5.64 \pm 0.08 A B$ \\
\hline & F3 & $2.62 \pm 0.12 \mathrm{~A}$ & $0.91 \pm 0.04 \mathrm{~A}$ & $3.53 \pm 0.16 \mathrm{~A}$ & $2.91 \pm 0.04 B$ & $0.65 \pm 0.02 \mathrm{~A}$ & $5.33 \pm 0.08 \mathrm{~A}$ \\
\hline & \multicolumn{7}{|c|}{ Two-way ANOVA } \\
\hline & Soil (S) & 0.024 & 0.042 & 0.025 & 0.941 & 0.031 & 0.120 \\
\hline & Foliar (F) & 0.627 & 0.566 & 0.847 & 0.003 & 0.203 & 0.010 \\
\hline & $\mathrm{S} \times \mathrm{F}$ & 0.916 & 0.586 & 0.840 & 0.118 & 0.923 & 0.395 \\
\hline 2016 & No & $2.19 \pm 0.09 a$ & $1.15 \pm 0.05 a$ & $3.33 \pm 0.14 a$ & $1.93 \pm 0.06 \mathrm{a}$ & $0.44 \pm 0.02 a$ & $7.32 \pm 0.25 \mathrm{a}$ \\
\hline \multirow[t]{3}{*}{ Soil } & $\mathrm{N} 25$ & $2.52 \pm 0.16 a b$ & $1.24 \pm 0.07 a b$ & $3.89 \pm 0.27 a b$ & $1.99 \pm 0.06 \mathrm{a}$ & $0.52 \pm 0.03 a b$ & $7.72 \pm 0.68 \mathrm{a}$ \\
\hline & N50 & $2.66 \pm 0.15 a b$ & $1.29 \pm 0.06 a b$ & $4.06 \pm 0.24 a b$ & $2.08 \pm 0.05 \mathrm{a}$ & $0.53 \pm 0.03 a b$ & $8.01 \pm 0.71 \mathrm{a}$ \\
\hline & N100 & $3.03 \pm 0.12 b$ & $1.49 \pm 0.06 b$ & $4.52 \pm 0.16 b$ & $2.12 \pm 0.08 \mathrm{a}$ & $0.62 \pm 0.04 b$ & $7.59 \pm 0.44 \mathrm{a}$ \\
\hline \multirow[t]{6}{*}{ Foliar } & F0 & $2.52 \pm 0.11 \mathrm{~A}$ & $1.28 \pm 0.05 \mathrm{~A}$ & $3.85 \pm 0.17 \mathrm{~A}$ & $1.98 \pm 0.04 \mathrm{~A}$ & $0.51 \pm 0.02 \mathrm{~A}$ & $7.76 \pm 0.38 \mathrm{~A}$ \\
\hline & F3 & $2.66 \pm 0.11 \mathrm{~A}$ & $1.29 \pm 0.05 \mathrm{~A}$ & $4.02 \pm 0.17 \mathrm{~A}$ & $2.08 \pm 0.05 \mathrm{~A}$ & $0.54 \pm 0.03 \mathrm{~A}$ & $7.64 \pm 0.45 \mathrm{~A}$ \\
\hline & \multicolumn{7}{|c|}{ Two-way ANOVA } \\
\hline & Soil (S) & 0.003 & 0.011 & 0.013 & 0.136 & 0.012 & 0.840 \\
\hline & Foliar (F) & 0.342 & 0.849 & 0.500 & 0.121 & 0.458 & 0.818 \\
\hline & $\mathrm{S} \times \mathrm{F}$ & 0.534 & 0.426 & 0.683 & 0.832 & 0.502 & 0.336 \\
\hline 2016 & No & $3.37 \pm 0.23 \mathrm{a}$ & $1.31 \pm 0.23 \mathrm{a}$ & $5.24 \pm 0.42 \mathrm{a}$ & $2.50 \pm 0.25 \mathrm{a}$ & $0.56 \pm 0.03 \mathrm{a}$ & $9.53 \pm 1.54 \mathrm{a}$ \\
\hline \multirow[t]{3}{*}{ Soil } & N25 & $3.61 \pm 0.21 \mathrm{a}$ & $1.34 \pm 0.22 \mathrm{a}$ & $5.48 \pm 0.42 \mathrm{a}$ & $2.28 \pm 0.24 \mathrm{a}$ & $0.52 \pm 0.05 \mathrm{a}$ & $11.75 \pm 1.78 \mathrm{a}$ \\
\hline & N50 & $3.55 \pm 0.19 \mathrm{a}$ & $1.36 \pm 0.22 \mathrm{a}$ & $5.58 \pm 0.34 \mathrm{a}$ & $2.47 \pm 0.23 \mathrm{a}$ & $0.59 \pm 0.05 \mathrm{a}$ & $10.06 \pm 1.27 \mathrm{a}$ \\
\hline & N100 & $3.70 \pm 0.20 \mathrm{a}$ & $1.52 \pm 0.16 \mathrm{a}$ & $5.90 \pm 0.46 \mathrm{a}$ & $2.19 \pm 0.19 \mathrm{a}$ & $0.58 \pm 0.05 \mathrm{a}$ & $11.02 \pm 2.04 \mathrm{a}$ \\
\hline \multirow[t]{6}{*}{ Foliar } & F0 & $3.33 \pm 0.20 \mathrm{~A}$ & $1.49 \pm 0.13 \mathrm{~A}$ & $5.76 \pm 0.26 \mathrm{~A}$ & $2.21 \pm 0.14 \mathrm{~A}$ & $0.55 \pm 0.03 \mathrm{~A}$ & $10.79 \pm 1.02 \mathrm{~A}$ \\
\hline & F3 & $3.54 \pm 0.16 \mathrm{~A}$ & $1.26 \pm 0.15 \mathrm{~A}$ & $5.28 \pm 0.31 \mathrm{~A}$ & $2.52 \pm 0.17 \mathrm{~A}$ & $0.56 \pm 0.03 \mathrm{~A}$ & $10.46 \pm 1.29 \mathrm{~A}$ \\
\hline & \multicolumn{7}{|c|}{ Two-way ANOVA } \\
\hline & Soil (S) & 0.754 & 0.818 & 0.676 & 0.607 & 0.740 & 0.793 \\
\hline & Foliar (F) & 0.961 & 0.348 & 0.326 & 0.177 & 0.873 & 0.959 \\
\hline & $\mathrm{S} \times \mathrm{F}$ & 0.164 & 0.790 & 0.290 & 0.509 & 0.926 & 0.259 \\
\hline
\end{tabular}

Significant differences are marked in italics

that $\mathrm{N}$ fertilization causes significant increases in fruit weight (Weinbaum et al. 1995). However, in this study, soil and foliar $\mathrm{N}$ fertilization did not influence fruit weight (nut and kernel) and fruit number of almond trees (Table 5). This differential result indicates that there are other factors behind fertilization that can directly affect nut size, such as pruning. As described previously, this almond orchard was subjected to heavy pruning in 2016, which affected the fruit characteristics in the year and the following year.

Previous studies have showed that an appropriate $\mathrm{N}$ rate is essential for improving photosynthetic efficiency (El-Sonbaty et al. 2012; Shangguan et al. 2000). In the present experiment, soil application of $\mathrm{N}$ favored higher annual values of all gas exchange parameters (Table 3). The maximum values of such parameters were observed at $25 \mathrm{~kg} \mathrm{~N} \mathrm{ha}^{-1}$, which superiority is closely related to photosynthetic $(A)$ and transpiration rates $(E)$ and stomatal conductance $\left(g_{\mathrm{s}}\right)$ (Fig. 2). An adequate availability of $\mathrm{N}$ can maintain the gas exchange process, stimulating the opening of the stomata, thereby increasing the stomatal conductance, transpiration, and rate of photosynthesis (Lambers et al. 1998; Proietti et al. 2012). On the contrary, none of the parameters related to leaf gas exchange was positively influenced by foliar $\mathrm{N}$ fertilization which should be due to the sufficient $\mathrm{N}$ concentration in leaves. In fact, Arrobas 
Fig. 5 PCA loading plot of leaf photosynthetic pigments measured in almond trees submitted to $\mathrm{N}$ soil (N0, N25, $\mathrm{N} 50$, and $\mathrm{N} 100)$ and $\mathrm{N}$ foliar (F0 and F3) fertilization throughout 2015-2017

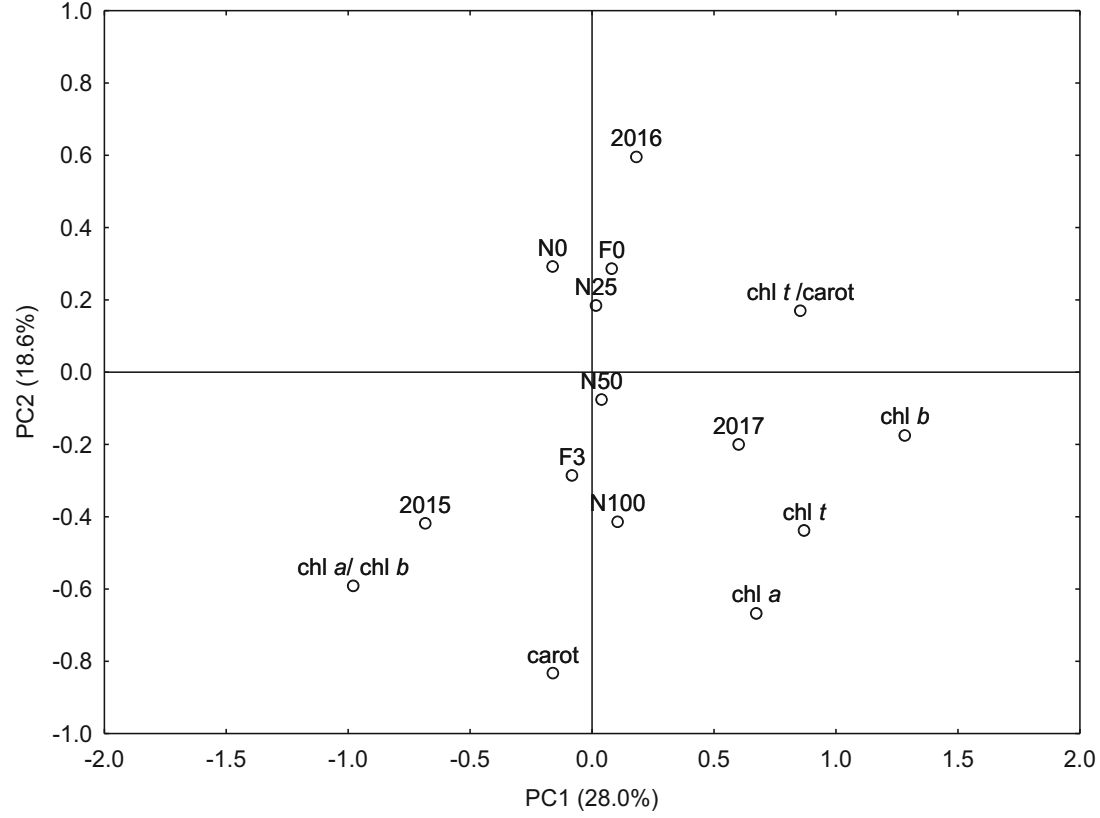

et al. (2019), for the same $\mathrm{N}$ rates, found that foliar application of $\mathrm{N}$ fertilizer had no significant effect on leaves $\mathrm{N}$ concentration. The lack of positive effect of foliar application of $\mathrm{N}$ on leaf photosynthesis was also reported by Regni and Proietti (2019) on olive tree. Since photosynthetic capacity is closely related to leaf $\mathrm{N}$ content (Makino 2011), it can be deduced that, under the conditions in which this experiment was carried out, almond trees did not benefit from a supplementary foliar $\mathrm{N}$ application. The maintenance of perfect physiological functions and growth is highly dependent on the plant water status (Saud et al. 2017). In the present study, soil $\mathrm{N}$ fertilization had little effect on leaf relative water content (RWC) (Fig. 3); however, its use can attenuate the negative effects of water shortage typical of rainfed conditions. In turn, the use of foliar sprays of $\mathrm{N}$ did not provide similar benefits. Regarding (EL), soil and foliar $\mathrm{N}$ fertilization did not have substantial effect on the integrity of cellular membranes (Fig. 4). Therefore, these results reveal that under the particular conditions of the present study, application of $\mathrm{N}$ to the soil would help almond plants to defense against reduced water availability. The response of almond trees to $\mathrm{N}$ fertilization was also evaluated based on biochemical traits, namely leaf photosynthetic pigments. Chlorophyll and carotenoid contents were clearly dependent on the year factor (Tables 1 and 2 and Fig. 5), being influenced by weather conditions throughout the year. Regarding the effect of $\mathrm{N}$ treatments (Table 4 ), the results
Fig. 6 Almond yield $\left(\mathrm{t} \mathrm{ha}^{-1}\right)$ throughout 2015-2017 and cumulative yield after three consecutive harvests. Data are means \pm standard error. Different lowercase letters indicate significant differences $(p<0.05)$ among $\mathrm{N}$ soil ( $\mathrm{N} 0, \mathrm{~N} 25, \mathrm{~N} 50$, and N100), and capital letters represent significant differences between $\mathrm{N}$ foliar (F0 and F3) treatments, according to Tukey's HSD test
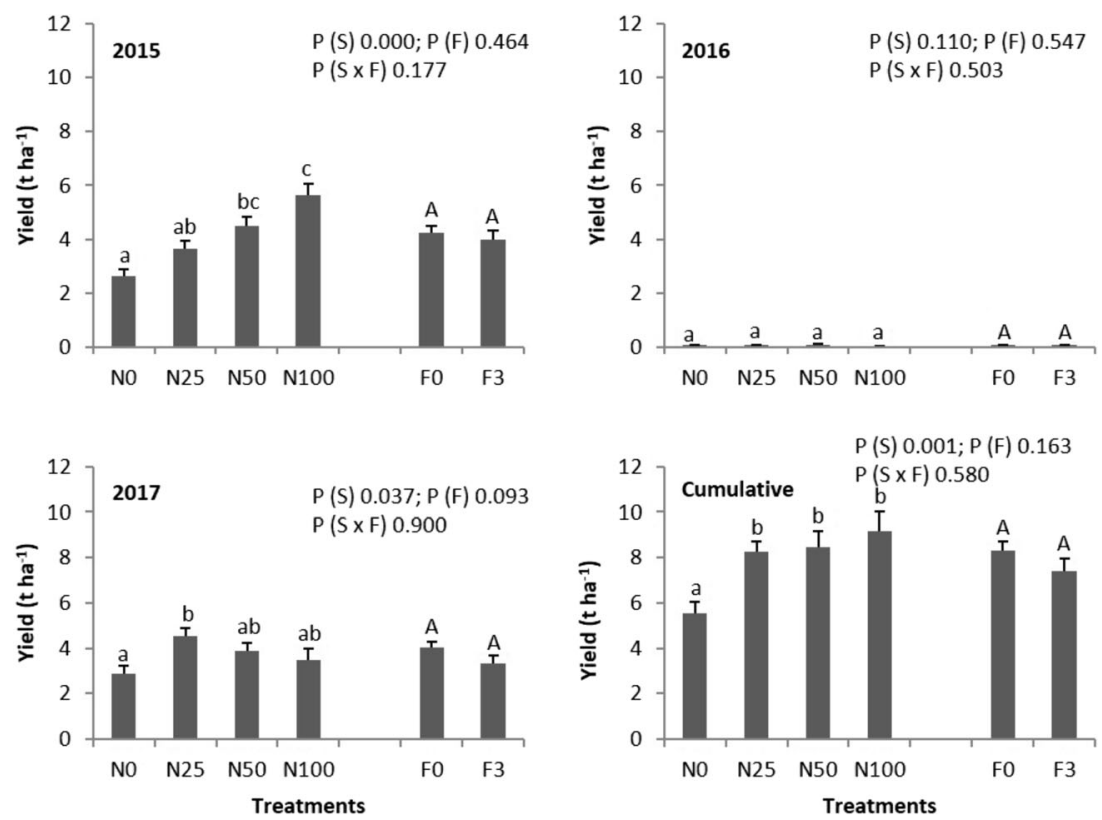
Table 5 Values (mean \pm standard error) of almonds per $\mathrm{kg}$, nut mass $(\mathrm{g})$, and kernel mass $(\mathrm{g})$ in the 2015-2017. Data are means \pm standard error. Following twoway ANOVA, for each parameter, different lowercase letters indicate significant differences $(p<0.05)$ among $\mathrm{N}$ soil (N0, N25, N50, and N100) and capital letters represent significant differences between $\mathrm{N}$ foliar (F0 and F3) treatments according to Tukey's HSD test

\begin{tabular}{|c|c|c|c|c|c|}
\hline Year & Fertilization & & Almonds per kg & Nut mass (g) & Kernel mass (g) \\
\hline \multirow[t]{10}{*}{2015} & \multirow[t]{4}{*}{ Soil } & No & $222 \pm 16 \mathrm{a}$ & $4.69 \pm 0.30 \mathrm{a}$ & $1.07 \pm 0.03 \mathrm{a}$ \\
\hline & & N25 & $220 \pm 15 \mathrm{a}$ & $4.78 \pm 0.36 \mathrm{a}$ & $1.10 \pm 0.06 \mathrm{a}$ \\
\hline & & N50 & $229 \pm 11 \mathrm{a}$ & $4.50 \pm 0.22 \mathrm{a}$ & $1.06 \pm 0.05 \mathrm{a}$ \\
\hline & & N100 & $247 \pm 26 \mathrm{a}$ & $4.30 \pm 0.32 \mathrm{a}$ & $1.10 \pm 0.07 \mathrm{a}$ \\
\hline & \multirow[t]{6}{*}{ Foliar } & F0 & $214 \pm 7 \mathrm{~A}$ & $4.83 \pm 0.17 \mathrm{~A}$ & $1.13 \pm 0.03 \mathrm{~A}$ \\
\hline & & F3 & $245 \pm 14 \mathrm{~A}$ & $4.31 \pm 0.22 \mathrm{~A}$ & $1.03 \pm 0.04 \mathrm{~A}$ \\
\hline & & \multicolumn{4}{|c|}{ Two-way ANOVA } \\
\hline & & Soil (S) & 0.686 & 0.693 & 0.956 \\
\hline & & Foliar (F) & 0.084 & 0.106 & 0.117 \\
\hline & & $\mathrm{S} \times \mathrm{F}$ & 0.643 & 0.730 & 0.844 \\
\hline \multirow[t]{10}{*}{2016} & \multirow[t]{4}{*}{ Soil } & No & $211 \pm 6 \mathrm{a}$ & $4.91 \pm 0.14 \mathrm{a}$ & $1.29 \pm 0.03 \mathrm{a}$ \\
\hline & & N25 & $210 \pm 5 \mathrm{a}$ & $4.94 \pm 0.12 \mathrm{a}$ & $1.37 \pm 0.04 \mathrm{a}$ \\
\hline & & N50 & $224 \pm 8 \mathrm{a}$ & $4.67 \pm 0.15 \mathrm{a}$ & $1.32 \pm 0.04 \mathrm{a}$ \\
\hline & & N100 & $241 \pm 11 \mathrm{a}$ & $4.34 \pm 0.18 \mathrm{a}$ & $1.32 \pm 0.04 \mathrm{a}$ \\
\hline & \multirow[t]{6}{*}{ Foliar } & F0 & $223 \pm 7 \mathrm{~A}$ & $4.69 \pm 0.13 \mathrm{~A}$ & $1.33 \pm 0.03 \mathrm{~A}$ \\
\hline & & F3 & $218 \pm 5 \mathrm{~A}$ & $4.79 \pm 0.11 \mathrm{~A}$ & $1.32 \pm 0.03 \mathrm{~A}$ \\
\hline & & \multicolumn{4}{|c|}{ Two-way ANOVA } \\
\hline & & Soil (S) & 0.061 & 0.071 & 0.550 \\
\hline & & Foliar (F) & 0.513 & 0.597 & 0.902 \\
\hline & & $\mathrm{S} \times \mathrm{F}$ & 0.212 & 0.337 & 0.534 \\
\hline \multirow[t]{10}{*}{2017} & \multirow[t]{4}{*}{ Soil } & No & $363 \pm 15 \mathrm{a}$ & $2.85 \pm 0.11 \mathrm{a}$ & $0.86 \pm 0.03 \mathrm{a}$ \\
\hline & & N25 & $363 \pm 9 \mathrm{a}$ & $2.87 \pm 0.07 \mathrm{a}$ & $0.87 \pm 0.03 \mathrm{a}$ \\
\hline & & N50 & $353 \pm 9 \mathrm{a}$ & $2.91 \pm 0.07 \mathrm{a}$ & $0.91 \pm 0.03 \mathrm{a}$ \\
\hline & & N100 & $341 \pm 12 \mathrm{a}$ & $3.04 \pm 0.13 \mathrm{a}$ & $0.95 \pm 0.05 \mathrm{a}$ \\
\hline & \multirow[t]{6}{*}{ Foliar } & F0 & $354 \pm 6 \mathrm{~A}$ & $2.90 \pm 0.05 \mathrm{~A}$ & $0.89 \pm 0.02 \mathrm{~A}$ \\
\hline & & F3 & $356 \pm 10 \mathrm{~A}$ & $2.95 \pm 0.09 \mathrm{~A}$ & $0.91 \pm 0.03 \mathrm{~A}$ \\
\hline & & \multicolumn{4}{|c|}{ Two-way ANOVA } \\
\hline & & Soil (S) & 0.441 & 0.518 & 0.289 \\
\hline & & Foliar $(\mathrm{F})$ & 0.717 & 0.798 & 0.655 \\
\hline & & $\mathrm{S} \times \mathrm{F}$ & 0.371 & 0.287 & 0.489 \\
\hline
\end{tabular}

revealed that application of $\mathrm{N}$ to the soil resulted in an advantageous response for almost all photosynthetic pigments evaluated in this study, mainly $\operatorname{chl} a, \operatorname{chl} b, \operatorname{chl} t$, and carot. This finding agrees with those obtained by Prsa et al. (2007) who found a significant increase in chlorophyll content and carotenoids with application of $\mathrm{N}$ fertilizer in apple tree. A similar effect was also observed in grapevines by Gutiérrez-Gamboa et al. (2018). The prime influence of $\mathrm{N}$ fertilization on photosynthetic pigments derived the fact that $\mathrm{N}$ is a structural element of chlorophyll and protein molecules and impacts the formation of chloroplasts and chlorophyll accumulation in them (Bojovič and Markovič 2009). Comparing both sources of $\mathrm{N}$, the best biochemical performance in terms of photosynthetic pigments was achieved with soil $\mathrm{N}$ application with no supplementation of $\mathrm{N}$, via foliar sprays (Table 4).

\section{Conclusions}

Under the conditions of this 3-year study, our results highlight for a beneficial effect of soil $\mathrm{N}$ fertilization on almond trees. Application of $\mathrm{N}$ to the soil influenced the physiological performance of almond trees with positive implications on yield. The supply of $\mathrm{N}$ via foliar fertilization $(0.5 \% \mathrm{~N}$ applied three times during the growing season) did not provide encouraging results since it failed to improve the physiological behavior and yield of almond. Considering the results of the present study collectively, and from an economic perspective, the best response of almond orchards under rainfed conditions to $\mathrm{N}$ fertilization is achieved by applying a reduced soil $\mathrm{N}$ rate of $25 \mathrm{~kg} \mathrm{ha}^{-1}$ per year. The adoption of this management practice ensures adequate soil fertility and increases productivity and 
Fig. 7 PCA loading plot of almond per kg, and almond (nut + kernel) mass under $\mathrm{N}$ soil $(\mathrm{N} 0$, $\mathrm{N} 25, \mathrm{~N} 50$, and $\mathrm{N} 100$ ) and $\mathrm{N}$ foliar (F0 and F3) fertilization throughout 2015-2017

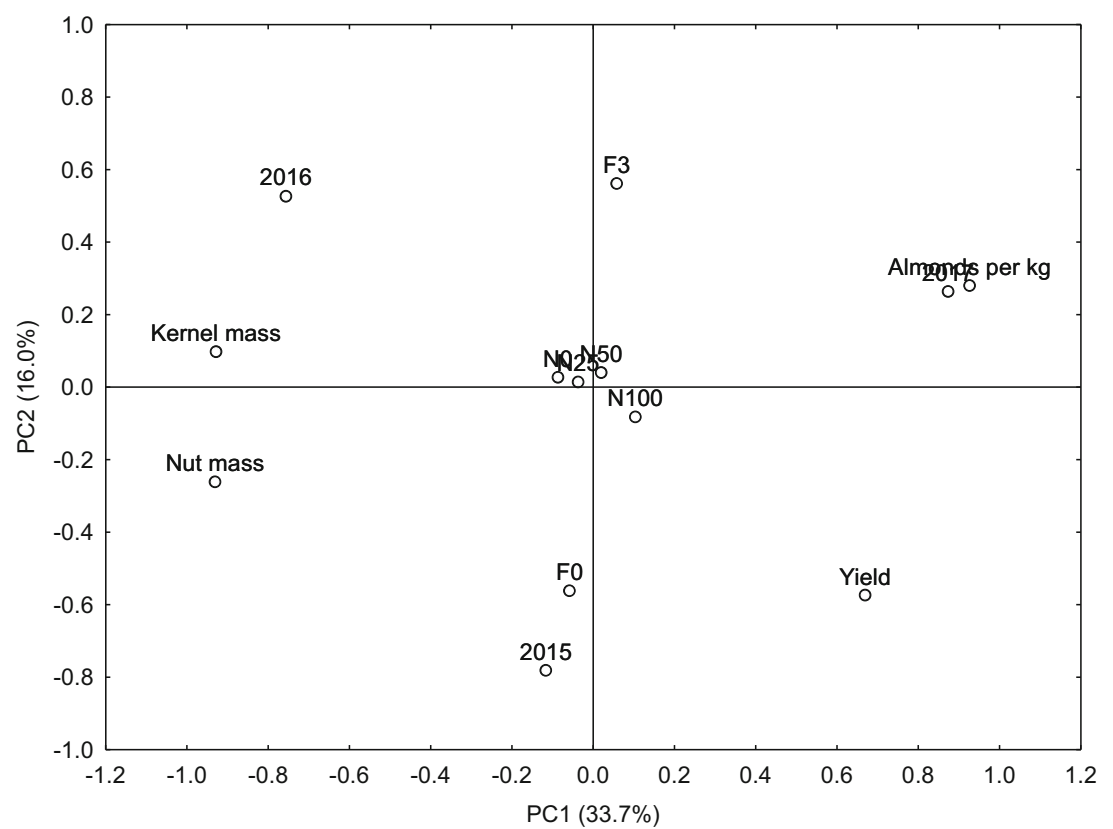

profitability of rainfed almond orchards, as well as the continuity of this traditional type of agriculture.

Acknowledgments The authors acknowledge the financial support of the European Agricultural and Rural development fund (FEADER) under the Project "Estratégias Integradas para o aumento da produtividade da amendoeira em Trás-os-Montes $n^{\circ}$ 54611," and by Portuguese State through the "Medida 4.1. Cooperação para a Inovação do programa PRODER - Programa de Desenvolvimento Rural." Maria Morais, Alfredo Aires, Berta Gonçalves, and Ana Silva acknowledge the support of the National Funds by FCT-Portuguese Foundation for Science and Technology, under the project UID/AGR/04033/2020. David Barreales, Manuel Rodrigues, and António Ribeiro are grateful to the Foundation for Science and Technology (FCT, Portugal) for financial support by national funds FCT/MCTES to CIMO (UID/AGR/00690/2018). The authors are also grateful to Ana Monteiro, Cristiana Teixeira, Iva Prgomet, Ivo Oliveira, Linton Dinis, Sara Bernardo, Sílvia Afonso, and Silvina Morais for their support in the field and in the laboratory.

\section{Compliance with Ethical Standards}

Conflict of Interest The authors declare that they have no conflict of interest.

\section{References}

Aires A, Morais MC, Barreales D, Rodrigues MÂ, Ribeiro AC, Gonçalves B, Silva AP (2018) Variation of almond yield, biometry, $\alpha$-tocopherol levels, and antioxidant properties with nitrogen fertilization. J Food Biochem:e12685. https://doi.org/10.1111/jfbc. 12685

Amiri ME, Fallahi E, Golchin A (2008) Influence of foliar and ground fertilization on yield, fruit quality, and soil, leaf, and fruit mineral nutrients in apple. J Plant Nutr 31:3515-3525. https://doi.org/10. 1080/01904160801895035

Arrobas M, Ribeiro A, Barreales D, Pereira EL, Rodrigues MA (2019) Soil and foliar nitrogen and boron fertilization of almond trees grown under rainfed conditions. Eur J Agron 106:39-48. https:// doi.org/10.1016/j.eja.2019.02.014

Bi G, Scagel CF, Cheng L, Fuchigami LH (2004) Soil and foliar nitrogen supply affects the composition of nitrogen and carbohydrates in young almond trees. J Hortic Sci Biotechnol 79(2):175-181. https://doi.org/10.1080/14620316.2004.11511745

Bojovič B, Markovič A (2009) Correlation between nitrogen and chlorophyll content in wheat (Triticum aestivum L.). Kragujevac J Sci 31: 69-74

Brown PH, Uriu K (1996) Nutrition deficiencies and toxicities: diagnosing and correcting imbalances. In: Micke WC (ed) Almond production manual. University of California, Division of Agriculture and Natural Resources, Publication 3364, pp 179-188

Carranca C, Brunetto G, Tagliavini M (2018) Nitrogen nutrition of fruit trees to reconcile productivity and environmental concerns. Plants 7(1):4. https://doi.org/10.3390/plants7010004

Cordeiro V, Monteiro A (2002) Almond growing in Trás-os-Montes region (Portugal). Acta Hortic 591:161-165. https://doi.org/10. 17660/ActaHortic.2002.591.22

El-Motaium RA, Shaban AEA, Badawy SH, Ibrahim ASA (2019) Alleviation of alternate bearing phenomenon in mango (Mangifera indica L.) trees using boron and nitrogen fertilization. J Plant Nutr 40(20):2861-2872. https://doi.org/10.1080/01904167.2019. 1659319

El-Sonbaty MR, Abd El-Naby SKM, Hegazi ES, Samira MM, ElSharony TF (2012) Effect of increasing fertilization levels on alternate bearing of olive cv. "Picual". Aust J Basic Appl Sci 6(10):608614

Famiani F, Proietti P, Palliotti A, Ferranti F, Antognozzi E (2000) Effect of leaf to fruit ratios on fruit growth in chestnut. Sci Hortic 85:145152. https://doi.org/10.1016/S0304-4238(99)00132-6

Filella I, Llusia J, Pin JO, Pen JU (1998) Leaf gas exchange and fluorescence of Phillyrea latifolia, Pistacia lentiscus and Quercus ilex saplings in severe drought and high temperature conditions. Environ 
Exp Bot 39:213-220. https://doi.org/10.1016/S0098-8472(97) 00045-2

Geisseler D, Horwath WR (n.d.) Almond nitrogen fertilizer guidelines. Fertilizer Research and Education Program, California Department of Food and Agriculture. Available https://www.cdfa.ca.gov/Is/ ffldrs/frep/pdfs/AlmondBrochureWeb.pdf Accessed 12 February 2019

Grzebisz W (2013) Crop response to magnesium fertilization as affected by nitrogen supply. Plant Soil 368:23-39. https://doi.org/10.1007/ s11104-012-1574-z

Gunes NT, Okay Y, Koksal AI, Koroglu M (2010) The effect of nitrogen and phosphorus fertilization on yield, some fruit characteristics, hormone concentrations, and alternate bearing in pistachio. Turk $\mathrm{J}$ Agric For 34:33-43. https://doi.org/10.3906/tar-0810-15

Gutiérrez-Gamboa G, Marín-San Román S, Jofré V, Rubio-Bretón P, Pérez-Álvarez EP, Garde-Cerdán T (2018) Effects on chlorophyll and carotenoid contents in different grape varieties (Vitis vinifera $\mathrm{L}$.) after nitrogen and elicitor foliar applications to the vineyard. Food Chem 269:380-386. https://doi.org/10.1016/j.foodchem.2018.07. 019

Hirel B, Tétu T, Lea PJ, Dubois F (2011) Improving nitrogen use efficiency in crops for sustainable agriculture. Sustainability 3(9):14521485. https://doi.org/10.3390/su3091452

Iacono F, Buccella A, Peterlunger E (1998) Water stress and rootstock influence on leaf gas exchange of grafted and ungrafted grapevines. Sci Hortic 75:27-39. https://doi.org/10.1016/S0304-4238(98) 00113-7

IPMA (2017) Boletim climatológico sazonal - Primavera de 2017. Available at http://wwwipmapt/resourceswww/docs/ i m public acoes/edicoesonline/20170627/ oCMBEVSTbkIvWfKNtVWP/cli_20170301_20170531_pcl_sz_ co ptpdf Accessed 15 November 2019

Khalsa SDS, Muhammad S, Brown PH (2017) Nitrogen budgeting for tree crops. In: Proceedings of Western nutrient management conference. Vol. 12, Reno, Nevada, pp 43-46

Kumar D, Ahmed N (2014) Response of nitrogen and potassium fertigation to "Waris" almond (Prunus dulcis) under Northwestern Himalayan Region of India. Sci World J 141328:1-6. https://doi. org/10.1155/2014/141328

Lambers H, Chapain FS III, Pons TL (1998) Plant physiological ecology. Springer, Berlin

Lichtenthaler HK (1987) Chlorophylls and carotenoids: pigments of photosynthetic biomembranes. Methods Enzymol 148:350-382. https:// doi.org/10.1016/0076-6879(87)48036-1

Lovatt CJ (2001) Properly timed soil-applied nitrogen fertilizer increases yield and fruit size of "Hass" avocado. J Amer Sco Hort Sci 126(5): 555-559. https://doi.org/10.21273/JASHS.126.5.555

LQARS (Laboratório Químico Agricola Rebelo da Silva) (2006) Manual de Fertilização das culturas. Instituto Nacional de Investigação Agrária, Lisboa

Lutts S, Kinet J, Bouharmont J (1996) NaCl-induced senescence in leaves of rice (Oryza sativa L.) cultivars differing in salinity resistance. Annals Bot 78:389-398. https://doi.org/10.1006/anbo.1996.0134

Makino A (2011) Photosynthesis, grain yield, and nitrogen utilization in rice and wheat. Plant Physiol 155:125-129. https://doi.org/10.1104/ pp. 110.165076

Mandapaka M, Murthy ANG, Shanker AK (2017) Nitrogen nutrition in crops and its importance in crop quality. In: Abrol YP, Adhya TK, Aneja VP, Raghuram N, Pathak H, Kulshrestha U, Sharma C, Singh B (eds) The Indian nitrogen assessment. Sources of reactive nitrogen, environmental and climate effects, management options, and policies. Elsevier Inc, pp 175-186
Muhammad S, Sanden BL, Saa S, Lampinen BD, Smart DR, Shackel KA, DeJong TM, Brown PH (2018) Optimization of nitrogen and potassium nutrition to improve yield and yield parameters of irrigated almond (Prunus dulcis (Mill.) D. A. Webb). Sci Hortic 228:204 212. https://doi.org/10.1016/j.scienta.2017.10.024

Neilsen GH, Neilsen D, Herbert L (2009) Nitrogen fertigation concentration and timing of application affect nitrogen nutrition, yield, firmness, and color of apples grown at high density. Hortscience 44: 1425-1431. https://doi.org/10.21273/HORTSCI.44.5.1425

O'Connell M, Whitfield D, Abuzar M (2016) Satellite remote sensing of vegetation cover and nitrogen status in almond. Acta Hortic 1130: 559-566. https://doi.org/10.17660/actahortic.2016.1130.84

Prgomet I, Gonçalves B, Domínguez-Perles R, Pascual-Seva N, Barros AIRNA (2017) Valorization challenges to almond residues: phytochemical composition and functional application. Molecules 22(10): E1774. https://doi.org/10.3390/molecules22101774

Proietti P, Nasini L, Ilarioni L (2012) Photosynthetic behaviour of Spanish Arbequina and Italian Maurino olive (Olea europaea L.) cultivars under super-intensive grove conditions. Photosynthetica 50(2):239-246. https://doi.org/10.1007/s11099-012-0025-7

Prsa I, Stampar F, Vodnik D, Veberic R (2007) Influence of nitrogen on leaf chlorophyll content and photosynthesis of "Golden Delicious" apple. Acta Agric Scand Sect B Soil Plant Sci 57(3):283-289. https://doi.org/10.1080/09064710600982878

Regni L, Proietti P (2019) Effects of nitrogen foliar fertilization on the vegetative and productive performance of the olive tree and on oil quality. Agriculture 9:252. https://doi.org/10.3390/ agriculture9120252

Reidel EJ, Brown PH, Duncan RA, Weinbaum SA (2001) Almond productivity as related to tissue potassium. Better Crops 85:21-23

Rodrigues MA, Pereira A, Cabanas JE, Dias L, Pires J, Arrobas M (2006) Crops use-efficiency of nitrogen from manures permitted in organic farming. Eur J Agron 25:328-335. https://doi.org/10.1016/j.eja. 2006.07.002

Rodrigues MÂ, Grade V, Barroso V, Pereira A, Cassol LC, Arrobas M (2020) Chestnut response to organo-mineral and controlled-release fertilizers in rainfed growing conditions. J Soil Sci Plant Nutr 20: 380-391. https://doi.org/10.1007/s42729-019-00119-7

Saa S, Peach-Fine E, Brown PH, Michailides TJ, Castro S, Bostock R, Laca E (2016) Nitrogen increases hull rot and interferes with the hull split phenology in almond (Prunus dulcis). Sci Hort 199:41-48. https://doi.org/10.1016/j.scienta.2015.12.027

Saa S, Fernández E, Muhammad S, Olivos-Del Rio A, DeJong TM, Laca E, Brown P (2017) Increases in the leaf nitrogen concentration and leaf area did not enhance spur survival and return bloom in almonds (Prunus dulcis (Mill.) DA Webb). Acta Physiol Plant 39:107. https://doi.org/10.1007/s11738-017-2401-1

Saud S, Fahad S, Yajun C, Ihsan MZ, Hammad HM, Nasin W, Amanullah J, Arif M, Alharby H (2017) Effects of nitrogen supply on water stress and recovery mechanisms in Kentucky bluegrass plants. Front Plant Sci 8:983. https://doi.org/10.3389/fpls.2017. 00983

Sesták Z, Castky J, Jarvis PG (1971) Plant photosynthetic production: manual of methods. Dr. W Junk Publ, Haia

Shangguan ZP, Shao MA, Dyckmans J (2000) Nitrogen nutrition and water stress effects on leaf photosynthetic gas exchange and water use efficiency in winter wheat. Environ Exp Bot 44:141-149. https://doi.org/10.1016/S0098-8472(00)00064-2

Valverde P, Carvalho M, Serralheiro R, Maia R, Ramos V, Oliveira B (2015) Climate change impacts on rainfed agriculture in the Guadiana river basin (Portugal). Agric. Water Manag 150:350 450. https://doi.org/10.1016/j.agwat.2014.11.008 
von Caemmerer S, Farquhar GD (1981) Some relationships between the bio-chemistry of photosynthesis and the gas exchange of leaves. Planta 153:376-387. https://doi.org/10.1007/BF00384257

Weinbaum SA, Johnson RS, DeJong TM (1992) Causes and consequences of over fertilization in orchards. Hort Technol 2:112-121. https://doi.org/10.21273/HORTTECH.2.1.112b

Weinbaum AS, Goldhamer D, Asai W, Niederholzer F (1994) Optimization of fertilizer $\mathrm{N}$ usage in almond orchards, 22th
Annual Almond Industry Conference Proceedings Almond Board of California, Modesto, pp 46-49

Weinbaum S, Brown P, Rosecrance R (1995) Assessment of nitrogen uptake capacity during the alternate bearing cycle. California Pistachio Industry, Annual Report. Crop Year 1994-1995

Publisher's note Springer Nature remains neutral with regard to jurisdictional claims in published maps and institutional affiliations. 